\title{
The impact of anthropogenic and environmental factors on the variability of Escherichia coli in rivers in southwest Bangladesh
}

\section{M. Majedul Islam ( $\square$ majed25bd@gmail.com )}

Ministry of Planning, Government of Bangladesh https://orcid.org/0000-0003-2448-6562

Md. Atikul Islam

Khulna University

\section{Research Article}

Keywords: Water quality, E. coli, physicochemical parameters, precipitation, temperature, correlation

Posted Date: September 15th, 2021

DOl: https://doi.org/10.21203/rs.3.rs-901563/v1

License: @ (i) This work is licensed under a Creative Commons Attribution 4.0 International License. Read Full License 


\section{Abstract}

Faecal contamination of surface water sources is an important water quality issue worldwide. Although quite a few studies exist on surface water faecal contamination and variability of indicator bacteria, most of the studies have been based on larger river basins and in temperate region. The variability is relatively unknown in local scale and in tropical developing countries. In this study we assess how anthropogenic and environmental factors affect faecal contamination and physicochemical parameters in Rupsha and Bhairab rivers around Khulna city, Bangladesh. Water samples were collected from six locations of the rivers during a wet and dry period in 2018 to measure Escherichia coli (E. coli) concentrations. Water physicochemical parameters-temperature, turbidity, $\mathrm{pH}$, dissolved oxygen, biochemical oxygen demand and chemical oxygen demand were also measured. Higher concentrations of $E$. coli were found in the sampling sites located near the densely populated urban area compared to the downstream site, which receives fewer amounts of discharges from sewer drains. All the $E$. coli samples violated bathing water quality standards. E. coli concentrations were found to be correlated positively with precipitation and turbidity. A linear regression model was applied, that explains large part of the variation in E. coli concentration $\left(R^{2}=0.42\right)$. Water quality index assessment was also ranked the water quality as 'poor' category; indicate that the water is unsuitable for uses in domestic and recreational purposes and high health risks involved with the water use. The study findings highlight the problem of untreated sewage discharge into the rivers. Implementation of sewage treatment plant with adequate capacity is highly recommended.

\section{Introduction}

Contamination of surface water sources can occur from different sources, such as surface runoff from urban areas and agricultural lands; untreated wastewater discharges; combined sewer overflow; septic tank leakage; and direct deposition of faeces by human, livestock and wildlife (Byappanahalli et al. 2012; Islam et al. 2017). The use of contaminated surface water for domestic purposes and recreational activities causes epidemics of waterborne diseases (Stocker et al. 2016). Globally, waterborne diseases are responsible for death of 1.8 million (estimated) people each year and most of these deaths are in developing countries children (under five years of age) (WHO 2012; Islam et al. 2018b). The Rupsha and Bhairab rivers in Bangladesh are a source of water for around 1.0 million residents living in the catchment area. Wastewaters and sewages are discharged into the rivers without any form of treatment. The contaminated river water is used for domestic purposes and bathing, which poses serious public health risks (Islam et al. 2017).

The health problem is likely to get worse in future because of climate change. Increased precipitation and higher water temperature due to climate change might influence the concentration and variability of river faecal indicator bacteria (FIB) (Hofstra 2011). Precipitation and temperature can influence FIB concentrations in different ways (Vermeulen and Hofstra 2013). The concentrations in surface water can increase after extreme precipitation events due to increased surface runoff, combined sewer overflow and re-suspension of deposited sediments (Funari et al. 2012; Hofstra 2011; Hong et al. 2010). At the same time, increased precipitation may dilute and therefore results in decreased concentration (Hofstra 2011; Vermeulen and Hofstra 2013). Decreased precipitation increases the proportion of wastewater in the surface water and thus increases the concentration (Nichols et al. 2009). Increased temperatures can reduce concentration by expediting the die-off rate of FIB (Walters et al. 2011; Vermeulen and Hofstra 2013). Higher temperatures may also favour bacteria growth and proliferation in the environment (Tiefenthaler et al. 2009; Hong et al. 2010; Abia et al. 2015). However, which factors are responsible how much for the overall variability in FIB concentrations is still not clear enough 
(Vermeulen and Hofstra 2013; Islam et al. 2017). Therefore, for better understanding, quantitative information on this mechanism is essential.

Considering the risks of infection associated with uses of contaminated surface waters, an enhanced understanding on the dynamics of FIB in water environment is important to reduce public health risks. Microbial quality of water sources needs to be assessed to prevent microbial infection and outbreak of waterborne diseases. Due to the difficulties in detection and enumeration of variety of pathogens, microbial quality of surface water is usually assessed by using FIB (WHO 2008; Lata et al. 2009; Islam et al. 2018b). Faecal coliform, E. coli and enterococci are commonly used as indicator (Lata et al. 2009; WHO 2012; Ouattara et al. 2013). Although FIB are mostly not pathogenic, their abundance in a water body indicates that other harmful pathogens might also present there (Burres 2009).

Environmental factors that affect microbial distribution in surface water sources need to be identified to reduce faecal contamination and mitigate health risks. However, at present most of the microbial monitoring studies have been based on ground waters, while the surface waters have been overlooked (Rochelle-Newall et al. 2015). Several studies have been assessed the influence of climatic and environmental variables on FIB in surface waters. In general, variation of FIB shows a general trend of higher concentrations during wet period and lower concentrations during dry period (Stocker et al. 2016; Abia et al. 2015; Martinez et al. 2014; Vermeulen and Hofstra 2013). Physicochemical factors such as temperature, turbidity, $\mathrm{pH}, \mathrm{DO}$, and nutrient concentrations have also been included in surface water microbial monitoring studies (e.g. Pachepsky et al. 2018; Ling et al. 2017; Momou et al. 2017; Stocker et al. 2016). However, most of the studies have been based on larger rivers and watersheds; it is relatively unknown what conditions and variability exist in smaller/local scale (Stocker et al. 2016). Besides, most of the studies have been conducted in developed countries and in temperate climate, quantitative study is still lacking in developing countries, particularly in (sub)tropical climate (Rochelle-Newall et al. 2015; Islam et al. 2017). Moreover, the sources of faecal contamination may differ among countries and regions, and the relative contribution of each source might also different. A better understanding of the contamination sources and variability of indicator bacteria is thus important.

This study aims at assessing the impact of anthropogenic activities (i.e. wastewater discharge) and environmental factors (i.e. water temperature, precipitation) on the variation in concentration of $E$. coli and water

physicochemical parameters during a wet and dry period. First, we explore the spatiotemporal variability of $E$. coli and physicochemical parameters and analyze the correlation among $E$. coli concentrations, environmental factors and parameters. Then, we estimate the contribution of these factors to $E$. coli variability by applying a multiple linear regression model. Finally, we evaluate the overall river water quality by using water quality index and discuss how the environmental factors influence $E$. coli concentrations in the river system. The findings will help water managers in managing surface water sources and contribute to the proposed water safety plan for the southwest region of Bangladesh.

\section{Methods}

\section{Study area}

The study sites were located in the Rupsha and Bhairab rivers near Khulna city (third largest city in Bangladesh). Six important industrial and populous sites (Fig. 1) near Khulna city was selected, five from the Rupsha and one 
from the Bhairab rivers. Water samples were obtained from the selected river sites to measure concentrations of E. coli and water physicochemical parameters, which include water temperature, $\mathrm{pH}$, salinity, turbidity, dissolved oxygen (DO), biochemical oxygen demand (BOD) and chemical oxygen demand (COD). All the sampling sites receive untreated sewage discharge from urban and industrial areas of the city through sewer drains except sampling site 6 (S6) which is located downstream. Besides, concentrations of $E$. coli were also measured from three sewer drains.

Figure 1 Sampling sites in the Rupsha and Bhairab rivers around Khulna city

\section{Sampling and analysis}

Sampling was conducted during a wet season (July-September) and a dry month (December) in 2018 (Table 1). During wet season, sampling was carried out on the day of or one day after rainfall event to assess the influence of precipitation on E. coli, and during December sampling was conducted when no rain was recorded for a week prior to the sampling. Water samples from the mentioned sites were collected (from one river bank) into sterile plastic bottles with the care and precaution required for bacteriological analysis and specified the standard methods (APHA 1998). Keeping in an ice box, the samples were brought to the laboratory of Environmental Science Discipline, Khulna University for analyses.

Analysis of E. coli was performed by the membrane filtration method 1103.1 (USEPA 2002). The details of this method have been described in our previous study (Islam et al. 2017). In brief: to enumerate number of $E$. coli, several dilutions of samples and triplicate plates for each dilution were considered. Diluted water samples were filtered through a membrane filter with a mesh size of $0.45 \mu \mathrm{m}$. The membrane thermotolerant $E$. coli (m-TEC) agar media was used and the plates were kept for incubation for two hours at $35 \pm 0.5^{\circ} \mathrm{C}$. The agar plates were further incubated for $22-24$ hours at $44.5 \pm 0.2^{\circ} \mathrm{C}$. The filters were then placed to a urea substrate pad for $15-20$ $\mathrm{min}$ and the $E$. colicolonies (yellow, yellow-brown, or yellow-green) were then counted as cfu/ $100 \mathrm{ml}$.

Water temperature (meter name: TLX, Dth-73), salinity (Hanna HI 8033), turbidity (Hach 2100Q), pH (Hanna HI 2211) and DO (Hanna HI 9146) were recorded on spot during sampling. Five-day BOD was measured following the method 5210B (APHA 1998). COD was measured by closed reflux titrimetric method 5220C (APHA 1998). Precipitation (total $\mathrm{mm} /$ day) data were obtained from Bangladesh Meteorological Department's station at Khulna.

\section{Statistical Analysis}

Statistical package software (SPSS) 26.0 was used for data analysis. The detail of statistical analysis has been presented in our previous study (Islam et al. 2017). In brief: to achieve a normal distribution, E. coli measured data were at first $\log _{10}$ transformed. All the data were normally distributed except precipitation, which was gamma distributed because of zero values in precipitation data (Vermeulen and Hofstra 2013; Islam et al. 2017). In our previous study (Islam et al. 2017), high E. coli concentrations were found in receiving waters at least three days after a rainfall event. Therefore, we summed the three days precipitation data, as was done in previous studies (Walters et al. 2011; Vermeulen and Hofstra 2013; Islam et al. 2017). A standard Pearson product-moment correlation analysis was performed for correlations among the factors. Spearman's rank correlation analysis was performed for correlation of $\log _{10} E$. coli concentrations with precipitation. 
To assess the net influences of environmental factors to the overall variability in river $E$. coli levels, the measured data were analyzed applying a multiple linear regression model. E. coli data were considered as dependent factors and other parameters were used as independent factors.

The model was formulated as follows (adopted from Islam et al. 2017):

$\log (Y)=\beta_{0}+\beta_{1} x_{i 1}+\beta_{2} x_{i 2} \ldots \beta_{p} x_{i p}+\epsilon i$, for $i=1,2, \ldots n$

where, $\mathrm{Y}$ is the average $E$. coli concentration (cfu/100 mL), $\beta i$ are constants, $\mathrm{X}_{\mathrm{i}}$ are the independent factors and $\nabla$ is residual error. We checked for collinearity and interaction effects among factors and no significant such effect was found. To assess the relative contribution of the factors to the model outcome, we ran the model keeping each independent factor out from the model. One-way ANOVA (analysis of variance) along with Tukey's post-hoc test was done to see the differences in the data and to assess the individual contribution of the factors to the total variations in $E$. coli concentration. The coefficient $R^{2}$ was used to measure the extent of the variability in $E$. coli concentrations. A correlation was considered significant when confidence level was $95 \%(p<0.05)$.

\section{Water Quality Index (WQI)}

The water quality of the river sampling sites was evaluated using WQI. This index can be used to define water quality of different water bodies for various uses such as domestic purposes, irrigation, water supply and recreational activities (Ling et al. 2017). In this study to assess WQI, eight parameters: $\log _{10}$ E. coli (EC), DO, BOD, $\mathrm{COD}, \mathrm{pH}$, temperature (Temp), salinity (Sal) and turbidity (Turb) were combined with their respective weights using the following equation (adopted from Ling et al. 2017 and Garcia et al. 2018):

\section{$\mathrm{WQI}=0.15 \times \mathrm{SI}_{\mathrm{EC}}+0.17 \times \mathrm{SI}_{\mathrm{DO}}+0.12 \times \mathrm{SI}_{\mathrm{BOD}}+$ $0.10 \times \mathrm{SI}_{\mathrm{COD}}+0.08 \times \mathrm{SI}_{\mathrm{Turb}}+0.10 \times \mathrm{SI}_{\mathrm{Temp}}+0.16 \times \mathrm{SI}_{\mathrm{Sal}}$ $+0.12 \times \mathrm{SI}_{\mathrm{pH}}$}

where $\mathrm{SI}$ is the sub-indices of those parameters. The evaluation ranges for the index classified the water as excellent (90-100), good (85-89), acceptable (80-84), bad (60-79) and poor (10-59) (Ling et al. 2017).

\section{Results}

\section{Spatiotemporal variations}

Concentrations of $E$. coli showed substantial spatiotemporal variations (Table 1, Fig. 2). Comparatively lower concentrations of E. coli were found at S6, located downstream and receive less sewer discharge from the Khulna city (Fig. 2). Higher concentrations observed in the sampling sites 2 and 3 (S2 and S3), which is near the populous area of the city and receive high sewage discharge through sewer drains. However, there was no statistically significant difference of $E$. coli concentrations among the river sampling sites. The observed mean $E$. coli concentrations in the rivers and sewer drains were $2.3 \times 10^{3}-5.4 \times 10^{4}$ and $5.4 \times 10^{5}-7.3 \times 10^{5} \mathrm{cfu} / 100 \mathrm{ml}$ respectively. Microbial water quality was found to be very unsatisfactory in each sampling sites, because the concentrations of $E$. coli were exceeded the USEPA specified bathing water quality threshold value of $126 \mathrm{cfu} / 100$ $\mathrm{ml}$ (geometric mean) and $235 \mathrm{cfu} / 100 \mathrm{ml}$ (single sample). 
No trends of substantial variations with time were found for the measured physicochemical parameters except water temperature and salinity. Lower temperatures were observed during winter and lower salinity was found during rainy season (July-September). Temperature, salinity and $\mathrm{pH}$ were found to have low spatial variability, with coefficients of variation (CVs) between 0 and 10\%. DO and $\log _{10} E$. coli concentrations displayed medium spatial variability, with CVs between 10 and 30\%. High levels of variation (CVs over 30\%) were found for turbidity, BOD and COD. The $\mathrm{pH}$ value of above 7 throughout the sampling period (Table 1) is the indication of no acidification of the river water. The average DO value of above $5 \mathrm{mg} / \mathrm{L}$ indicates that the river water was well oxygenated.

Table 1

Spatiotemporal variability of $\log _{10}$ E. coli concentrations and environmental factors

\begin{tabular}{|c|c|c|c|c|c|c|}
\hline \multirow[t]{2}{*}{ Parameters } & \multicolumn{6}{|c|}{ Ave value \pm SD on the sampling dates } \\
\hline & 9 Jul 2018 & $\begin{array}{l}25 \mathrm{Jul} \\
2018\end{array}$ & $\begin{array}{l}12 \text { Aug } \\
2018\end{array}$ & $\begin{array}{l}5 \text { Sept } \\
2018\end{array}$ & 5 Dec 2018 & $\begin{array}{l}20 \text { Dec } \\
2018\end{array}$ \\
\hline $\begin{array}{l}\text { Log E. coli } \\
\text { (cfu/100ml) }\end{array}$ & $3.39 \pm 0.46$ & $4.73 \pm 0.35$ & $4.52 \pm 0.32$ & $\begin{array}{l}4.68 \pm \\
0.26\end{array}$ & $4.33 \pm 0.51$ & $4.26 \pm 0.33$ \\
\hline Temperature $\left({ }^{\circ} \mathrm{C}\right)$ & $32.4 \pm 0.1$ & $30.0 \pm 1.1$ & $30.3 \pm 0.4$ & $\begin{array}{l}30.15 \pm \\
0.9\end{array}$ & $24.9 \pm 0.1$ & $22.1 \pm 0.2$ \\
\hline $\mathrm{pH}$ & $7.4 \pm 0.1$ & $7.3 \pm 0.2$ & $7.3 \pm 0.1$ & $7.5 \pm 0.3$ & $7.4 \pm 0.2$ & $7.6 \pm 0.1$ \\
\hline Turbidity (NTU) & $\begin{array}{l}163.8 \pm \\
48.7\end{array}$ & $\begin{array}{l}281.2 \pm \\
59.8\end{array}$ & $\begin{array}{l}247.3 \pm \\
117.1\end{array}$ & $\begin{array}{l}319.6 \pm \\
87.7\end{array}$ & $\begin{array}{l}225.3 \pm \\
105.3\end{array}$ & $\begin{array}{l}213.4 \pm \\
74.3\end{array}$ \\
\hline Salinity (ppt) & $0.13 \pm 0.14$ & $0.16 \pm 0.18$ & $0.14 \pm 0.05$ & $\begin{array}{l}0.34 \pm \\
0.09\end{array}$ & $0.43 \pm 0.08$ & $0.6 \pm 0.16$ \\
\hline $\mathrm{DO}(\mathrm{mg} / \mathrm{l})$ & $5.7 \pm 0.8$ & $5.8 \pm 1.1$ & $6.1 \pm 1.3$ & $5.7 \pm 1.4$ & $5.5 \pm 1.6$ & $5.4 \pm 1.2$ \\
\hline $\mathrm{BOD}(\mathrm{mg} / \mathrm{l})$ & $19.3 \pm 7.4$ & $8.2 \pm 4.2$ & $15.9 \pm 5.8$ & $\begin{array}{l}25.2 \pm \\
13.2\end{array}$ & $3.8 \pm 2.7$ & $2.9 \pm 1.6$ \\
\hline $\mathrm{COD}(\mathrm{mg} / \mathrm{l})$ & $\begin{array}{l}266.3 \pm \\
113.2\end{array}$ & $\begin{array}{l}200.4 \pm \\
112.2\end{array}$ & $\begin{array}{l}165.4 \pm \\
67.8\end{array}$ & $\begin{array}{l}318.1 \pm \\
92.6\end{array}$ & $64.8 \pm 57.8$ & $27.2 \pm 8.4$ \\
\hline
\end{tabular}

Figure 2 Average E. coli concentrations over the six river sites with standard errors

E. coli concentrations showed a clear seasonality with higher average concentrations occurring during wet weather in the monsoon (July to September), compared to the dry period (Fig. 3). After rainfall events occurred during the 25th July and 5th September (Fig. 3), E. coli concentrations were increased by about one order of magnitude compared to the measured concentrations during dry weather conditions. However, E. coli concentrations were not always consistent with the amount of precipitation. The lowest concentrations measured in the study occurred during a smaller precipitation event ( $5 \mathrm{~mm} /$ day) on the 9 th July (first sampling day) (Fig. 3).

Figure 3 Average E. coli concentrations (cfu/100 mL) with standard errors, water temperature $\left({ }^{\circ} \mathrm{C}\right.$ ) and total recorded rainfall ( $\mathrm{mm}$, summed over 3 days preceding the sampling day) over the six river sites.

\section{Correlations}


Table 2 shows correlation among $\log _{10}$ E. coli, precipitation and other environmental factors. Figure 3 presents the correlation of $\log _{10} E$. coli concentrations with water temperature, precipitation, turbidity and salinity average over the river sites. Statistically non-significant positive correlation was found between $E$. coli concentrations with precipitation $(R=0.42)$ and turbidity $(R=0.31)$. E. coli also showed non-significant negative correlation with temperature, salinity, DO and COD. E. coli was found to have a very weak correlation with $\mathrm{pH}$, and BOD.

Precipitation showed a significant positive correlation with temperature and COD; and a non-significant positive correlation with turbidity, DO and BOD. Temperature showed significant negative correlation with $\mathrm{pH}$ and salinity; and significant positive correlation with COD. Water $\mathrm{pH}$ showed a moderate negative correlation with turbidity, DO, BOD and COD.

Table 2

Correlations among E. coli ( $\log _{10}$ transformed) and environmental factors. Values were averaged over the sampling sites. Pearson's product-moment correlation was applied for correlation analysis of the factors except for precipitation. Spearman's rank correlation was applied for precipitation (summed over three days prior to the sampling dates). Correlation coefficients indicated with * are significant at $p<0.05$.

\begin{tabular}{|c|c|c|c|c|c|c|c|c|c|}
\hline \multirow[t]{2}{*}{ Parameters } & \multicolumn{9}{|c|}{ Correlation coefficients } \\
\hline & $\begin{array}{l}E . \\
\text { coli }\end{array}$ & Precipitation & Temperature & $\mathrm{pH}$ & Turbidity & Salinity & DO & BOD & COD \\
\hline E. coli & 1 & 0.42 & -0.33 & 0.06 & 0.31 & -0.19 & -0.18 & 0.07 & -0.21 \\
\hline Precipitation & & 1 & $0.55^{\star}$ & -0.33 & 0.44 & $-0.57 *$ & 0.21 & 0.11 & 0.65 \\
\hline Temperature & & & 1 & $-0.58^{*}$ & 0.02 & $-0.51^{\star}$ & 0.16 & 0.28 & $0.66^{\prime}$ \\
\hline $\mathrm{pH}$ & & & & 1 & -0.37 & 0.04 & -0.28 & -0.26 & -0.22 \\
\hline Turbidity & & & & & 1 & 0.02 & 0.07 & 0.15 & -0.09 \\
\hline Salinity & & & & & & 1 & -0.13 & 0.25 & -0.27 \\
\hline DO & & & & & & & 1 & 0.27 & 0.07 \\
\hline BOD & & & & & & & & 1 & 0.44 \\
\hline COD & & & & & & & & & 1 \\
\hline
\end{tabular}

Figure 4 Correlations of $\log _{10}$ E. coli (average over the river sites) with precipitation, water temperature, salinity and turbidity.

\section{Statistical modelling}

A linear regression model was developed to estimate the combined impact of the important environmental factors on river $E$. coli concentration. The model generated an adjusted $R^{2}$ value of 0.42 for $E$. coli. We studied the influence of each environmental factors on $E$. coli concentrations separately. The model result showed that two independent factors, precipitation and water temperature contributed largely to the variations in mean $E$. coli concentrations. We eliminated other factors ( $\mathrm{pH}, \mathrm{DO}, \mathrm{BOD}, \mathrm{COD}$, turbidity and salinity) from the final model, as these did not show substantial influences on E. coli variability. According to the correlation analysis (Sect. 3.2) turbidity, salinity, BOD and COD showed weak correlation with E. coli and including these factors in the regression analysis did not improve the model fit, meaning that contribution of these factors to the model is little. 


\section{Water Quality Index}

Figure 5 shows the WQI of Rupsha and Bhairab rivers, categorized into dry, wet and overall the sampling periods. Conditions were considered dry if no rainfall had occurred within seven days prior to the sampling date and were considered wet if samples were taken within three days of rainfall. The result showed that the river's water quality was ranked in the 'poor' category (based on the classification presented in Sect. 2.4), indicates that the water quality is frequently impaired and often deviated from desired level. The WQI of overall and dry season showed a difference of 1.6 units, and the difference between dry and wet seasons was of 3.5 units (Fig. 5).

Figure 5 Water quality index of Rupsha and Bhairab rivers, average over the sampling sites.

\section{Discussion}

Different environmental factors particularly precipitation and temperature influence the spatiotemporal variability of $E$. coli and water physicochemical parameters. Influence of rainfall on water bodies is a major concern particularly in a tropical country, where seasonal variations of surface water quality are primarily dominated by precipitation (Vermeulen and Hofstra 2013). A rainfall event can greatly influence the physicochemical characteristics of a surface water body by altering its hydrology and bringing contaminants into the water source via surface runoff (Ling et al. 2017). In the study area, rainy season and summer coincide (Islam et al. 2017), which is reflected by the observed significant positive correlation $(R=0.55)$ between temperature and precipitation.

The results showed elevated turbidity after rainfall events (correlation between turbidity and precipitation is 0.44 ), which was probably due to the resuspension of deposited sediment under high flow condition. This is supported by previous studies (e.g. Ling et al. 2017; Munoz-Nava et al. 2018). A significant positive correlation was found between COD and rainfall data, which shows the effects of rainfall on increasing the pollution load in the rivers. This is also in agreement with the study of Momou et al. (2017).

The weak correlation of $E$. coli concentration with $\mathrm{pH}, \mathrm{DO}$ and $\mathrm{BOD}$ could be due to the relatively small spatiotemporal variation of these parameters, which allowed other parameters to have a stronger influence on $E$. coli concentrations. Weak influence of these parameters was also reported in other studies (e.g. Stocker et al. 2016; Momou et al. 2017).

Higher E. coli concentrations were observed during wet period compared to dry period, which agrees with previous studies (Walters et al. 2011; Abia et al. 2015; Aragonés et al. 2016). Precipitation was correlated positively with $E$. coli, because surface water can be contaminated with urban runoff, combined sewer overflow and resuspension from deposited sediments. Similar reasons regarding the positive correlations were also pointed out in previous studies (e.g. Ibekwe et al. 2011; Martinez et al. 2014; Aragonés et al. 2016; Islam et al. 2017). Water temperature and salinity showed negative correlation with $E$. coliconcentrations. This is consistent with the results from previous studies (Adingra et al. 2012; Dastager 2015; Aragonés et al. 2016). Water temperature facilitates bacterial die-off, could be the reason of negative correlation. In southwest Bangladesh during monsoon (JulySeptember), precipitation increases and water salinity reduce to below 1 ppt (Islam et al. 2017). The negative correlation with salinity was not due to the salinity induced die-off of $E$. coli, it might be due to the coincidence of low salinity with increased monsoon precipitation. 
The regression model explains large part of the variation in $E$. coli concentration $\left(R^{2}=0.42\right)$ by taking different environmental parameters into account. The model results agree well with other studies that included similar parameters with this study, e.g. $R^{2}$ of 0.46 in our previous study in the Betna river in Bangladesh (Islam et al. 2017); $R^{2}$ of 0.20-0.41 in 23 sea beaches in Chicago (Whitman and Nevers 2008); $R^{2}$ of 0.49-0.68 in Ribble drainage basin in the UK (Kay et al. 2005); and $R^{2}$ of 0.49 in the Rhine, Meuse and Drentse Aa (Vermeulen and Hofstra 2013). The regression results indicate that water temperature and precipitation is the most important factors that can influence river faecal contamination greatly.

The measured mean E. coli concentrations (3.4-4.7 log cfu/100 mL) of this study are higher than our previous study (Islam et al., 2017) in Bangladesh (2.9-3.4) and the study of Liu et al. (2009) in China (1.8-3.4); but comparable with the study of Widmer et al. (2013) in Southeast Asia (2.8-4.3) and Adingra et al. (2012) in Côte d'Ivoire (2.55-3.47). All the E. coli samples violated the USEPA specified bathing water quality standards. The high $E$. coli concentrations and violation of standard are not strange for the study area, as a large volume of sewages from a densely populated urban area enter directly to the rivers without any treatment. These results indicate potential health risks with the use of the river water. A quantitative microbial health risk assessment is very essential, that can be a basis for reducing disease burden from microbial contamination.

The WQI in the river sampling sites after rain showed little improvement mainly due to dilution of $E$. coli concentrations and an increase in the DO level. The rainfall affected positively the river water quality and increased the index slightly compared to the dry period. However, rainfall events did not improve the rivers water quality substantially, which indicates that influence of seasonal changes to the rivers water quality is little. The overall WQI indicates poor quality of river water. When a water quality is poor, the water is unsuitable for use in domestic and recreational purposes, and has limited potential for aquaculture and irrigation (Munoz-Nava et al. 2018). The river water is currently being used for domestic purposes (e.g. washing cloths and utensils), bathing, fishing, discharging of untreated sewage and open defecation. All these practices are causing serious threat to the biodiversity of the river and public health by altering the physicochemical properties and increasing microbial concentrations of the river system.

The observed comparatively higher E. coli concentrations in the S2 and S3 sampling sites located near the populous area of the Khulna city and receive high sewage discharge through sewer drains; and lower concentrations at S6 located downstream and receive less sewer discharge from the city indicate that untreated wastewater from the sewer drains was the major contamination source in the rivers. Introduction of adequate level of wastewater treatment could result in considerable improvement of the river microbial water quality. This is also supported by other studies (Islam et al. 2018b; Vijay et al. 2016; Liu et al. 2015; Ouattara et al. 2013). Therefore, establishment of wastewater treatment plants to treat wastewater before it is discharged into the rivers are urgently needed. The current level of faecal contamination in the rivers is already very high. This could be further deteriorated by the increasing population growth, urbanization, and intensification of agriculture and aquaculture. As a result, uses of the highly contaminated river water will increase public health risks. Although establishment of effluent treatment plants has become mandatory for industries, there is no such strict regulation and initiative to establish domestic wastewater treatment plants in Bangladesh (Islam et al. 2018a). The implementation of wastewater treatment is a must to achieve the UN Sustainable Development Goal (SDG) 6 target 3 'to halve the proportion of untreated wastewater' (UN-Water 2017; Islam et al. 2018a). At least secondary level of wastewater treatment should be established immediately in the highly populated city area (Islam et al. 
2018a). Otherwise it will be impossible for Bangladesh to treat the increasing amount of waste and achieve SDG 6.3 by 2030 .

\section{Conclusions}

The monitoring study conducted in the two rivers running along Khulna city revealed substantial spatiotemporal variations in E. coli concentrations. The concentrations were higher during the wet period compared to the dry period. Precipitation and turbidity were correlated positively and water temperature and salinity correlated negatively with $E$. coli concentrations. Our regression model can explain $42 \%$ of $E$. coli variability in river water taking into account the factors water temperature and precipitation. This study explores the existence of a consistently high concentration of $E$. coli across the Rupsha and Bhairab river study sites. Comparatively higher $E$. coli concentrations were found in the sampling sites that receive high inflow of sewage through sewer drains. All the $E$. coli samples exceeded USEPA specified bathing water quality standards and according to WQI evaluation the water quality is poor. Therefore, the river water within the study locations was not suitable for domestic and recreational purposes. The untreated industrial and domestic wastewater, through urban drainage system was identified as the major factors causing river water quality deterioration. Continuous water quality monitoring and implementation of adequate wastewater treatment facilities is very important if the water has to use for domestic and recreational/bathing purposes. A comprehensive water management strategy and enforcement of environmental laws are urgently needed to protect water quality of the rivers.

\section{Declarations}

\section{Acknowledgement}

We thank Bangabandhu fellowship trust authority in the Ministry of Science and Technology, Government of Bangladesh for providing a fellowship to conduct this research. We thank the Environmental Science Discipline, Khulna University, Bangladesh for providing us with laboratory facilities.

\section{Compliance with ethical standards}

This article does not contain any studies with human or animal subjects.

\section{Authors' contributions}

Both of the authors contributed to the study conception and implementation. The first draft of the manuscript was written by the first author M.M. Majedul Islam and the other author proofread and approved the final manuscript.

\section{Conflict of interest}

We declare that there is no conflict of interest.

\section{Funding}

The study was financially supported by the Ministry of Science and Technology, Government of Bangladesh for the year 2018 . 


\section{Data Availability}

The datasets generated during and/or analysed during the current study are available from the corresponding author on request.

\section{References}

1. Abia ALK, Ubomba-Jaswa E, Momba MNB (2015) Impact of seasonal variation on Escherichia coli concentrations in the riverbed sediments in the Apies River, South Africa. Science of the Total Environment, $537,462-469$

2. Adingra A, Kouadio A, Blé $M$, Kouassi $A$ (2012) Bacteriological analysis of surface water collected from the Grand-Lahou lagoon, Côte d'ivoire. African Journal of Microbiologial Research 6(13):3097-3105

3. APHA (1998) Standard methods for the examination of water and wastewater, 18th edn. American Public Health Association, Washington DC

4. Aragonés L, López I, Palazón A, López-Úbeda R, García C (2016) Evaluation of the quality of coastal bathing waters in Spain through fecal bacteria Escherichia coli and Enterococcus. Science of the Total Environment 566:288-297

5. Burres E (2009) Surface Water Ambient Monitoring Program Using IDEXX For Fecal Indicator Bacteria Monitoring SWRCB-Clean Water Team: Canada, pp. 576-678

6. Byappanahalli MN, Shively DA, Nevers MB, Sadowsky MJ, Whitman RL (2003) Growth and survival of Escherichia coli and enterococci populations in the macro-alga Cladophora. FEMS Microbiology Ecology 46:203-211

7. Dastager SG (2015) Assessment of enteric bacterial indicators and correlation with physico-chemical parameters in Veraval coast, India. Indian Journal of Geo-Marine Sciences 44(4):32-46

8. Funari E, Manganelli M, Sinisi L (2012) Impact of climate change on waterborne diseases. Ann Ist Super Sanità 48:473-487

9. Garcia CAB, Igor SV, Maria CSM, Helenice LG (2018) Evaluation of water quality indices: use, evolution and future perspectives. Advances in Environmental Monitoring Assessment 3:1-13

10. Hofstra N (2011) Quantifying the impact of climate change on enteric waterborne pathogen concentrations in surface water. Current Opinion Environmental Sustainability 3:471-479

11. Hofstra N, Vermeulen LC (2016) Impacts of population growth, urbanisation and sanitation changes on global human Cryptosporidium emissions to surface water. International Journal of Hygiene Environmental Health 219(7):599-605

12. Hong H, Qiu J, Liang Y (2010) Environmental factors influencing the distribution of total and faecal coliform bacteria in six water storage reservoirs in the Pearl River Delta region, China. Journal of Environmental Science 22:663-668

13. Ibekwe AM, Lesch S, Bold R, Leddy M, Graves A (2011) Variations of indicator bacteria in a large urban watershed. T ASABE 54:2227-2236

14. Islam MMM, Hofstra N, Islam MA (2017) The impact of environmental variables on faecal indicator bacteria in the Betna River basin, Bangladesh. Environmental Processes 4:319-332 
15. Islam MMM, Sokolova E, Hofstra N (2018a) Modelling of river faecal indicator bacteria dynamics as a basis for faecal contamination reduction. J Hydrol 563:1000-1008

16. Islam MMM, Iqbal MS, Leemans R, Hofstra N (2018b) Modelling the impact of future socio-economic and climate change scenarios on river microbial water quality. International Journal of Hygiene environmental Health 221(2):283-292

17. Kay D et al (2005) Predicting faecal indicator fluxes using digital land use data in the UK's sentinel water framework directive catchment: the Ribble study. Water Res 39:3967-3981

18. Lata P, Ram S, Agrawal M, Shanker R (2009) Enterococci in river Ganga surface waters: propensity of species distribution, dissemination of antimicrobial-resistance and virulence-markers among species along landscape. BMC microbiology 9(1):140-156

19. Ling TY, Chen-Lin S, Jing-Jing L, Lee N, Siong-Fong S ., \& Jongkar G (2017) Influence of Rainfall on the Physicochemical Characteristics of a Tropical River in Sarawak, Malaysia. Polish Journal of Environmental Studies 26(5):1 2053-2065.

20. Liu W-C, Chan W-T, Young C-C (2015) Modelling fecal coliform contamination in a tidal Danshuei River estuarine system. Sci Total Environ 502:632-640

21. Liu Y, Zhang C, Wang X (2009) Simultaneous detection of enteric bacteria from surface waters by QPCR in comparison with conventional bacterial indicators. Environ Monit Assess 158:535-544

22. Martinez G, Pachepsky YA, Whelan G, Yakirevich AM, Guber A, Gish TJ (2014) Rainfall-induced faecal indicator organisms transport from manured fields: model sensitivity analysis. Environ Int 63:121-129

23. Momou KJ, Chantal AK, Karim ST, Djako SK, Mireille D (2017) Effects of rainfalls variability and physicalchemical parameters, on enteroviruses in sewage and lagoon in Yopougon, Co`te d'Ivoire. Applied Water Science 7:2075-2087

24. Munoz-Nava H, Juan S, Rafael VQ, Silvia CC, Maria IBC, Karina GV (2018) Influence of dry and rainy seasons on physicochemical parameters and water quality index, Zahuapan River, Mexico. Journal of Environment Earth Science 8(8):1-9

25. Ouattara NK, de Brauwere A, Billen G, Servais P (2013) Modelling faecal contamination in the Scheldt drainage network. J Mar Syst 128:77-88

26. Pachepsky Y, Rachel K, Matthew S, Kevin S, Walter M, Hoonsoo L, Moon K (2018) Temporal stability of Escherichia coli concentrations in waters of two irrigation ponds in Maryland. Appl Environ Microbiol 84(3):1-12

27. Rochelle-Newall E,. Nguyen TMH, Le TPQ, Sengtaheuanghoung O, Ribolzi O (2015) A short review of fecal indicator bacteria in tropical aquatic ecosystems: knowledge gaps and future directions. Frontier of Microbiology 6:1-15

28. Stocker MD, Rodriguez-Valentín JG, Pachepsky YA, Shelton DR (2016) Spatial and temporal variation of fecal indicator organisms in two creeks in Beltsville, Maryland. Water Qual Res J Can 52(7):167-179

29. Tiefenthaler LL, Stein ED, Lyon GS (2009) Faecal indicator bacteria (FIB) levels during dry weather from Southern California reference streams. Environ Monit Assess 155:477-492

30. UN-Water (2017) Integrated Monitoring Guide for Sustainable Development Goal 6 \&\#8211

31. Targets and global indicators (file:///C:/Users/DPD\%20NHP/Downloads/EN_G2_SDG-6-targets-andindicators_Version-2017-07-14.pdf), Accessed on 01.25.2018 
32. USEPA (2002) Method 1103.1: Escherichia coli (E. coli) in water by membrane filtration using membraneThermotolerant E. coli agar (mTEC). US EPA Office of water, Washington DC

33. Vermeulen L, Hofstra N (2013) Influence of climate factors on the concentration of Escherichia coli in the Rhine, Meuse, and Drentse Aa during 1985-2010. Reg Environ Change 14:307-319

34. Vijay R, Mardikar T, Kumar R (2016) Impact of sewage discharges on coastal water quality of Mumbai, India: present and future scenarios. Environ Monit Assess 188(7):1-13

35. Walters SP, Thebo AL, Boehm AB (2011) Impact of urbanization and agriculture on the occurrence of bacterial pathogens and stx genes in coastal waterbodies of central California. Water Res 45(4):1752-1762

36. Widmer K et al (2013) Prevalence of Escherichia coli in surface waters of Southeast Asian cities. World Journal of Microbiology Biotechnology 29:2115-2124

37. Whitman RL, Nevers MB (2008) Summer E. colipatterns and responses along 23 Chicago beaches. Environ Sci Technol 42:9217-9224

38. WHO (2008) World Health Organisation's guideline for drinking water quality, 3rd edition, V. 1. https://www.who.int/water_sanitation_health/publications/gdwq3rev/en/, Accessed on 27/10/2018

39. WHO (2012) World Health Organisation Global Data Repository. Available at: http://apps.who.int/ghodata/:WorldHealthOrganisation, Accessed on 23/08/2018

\section{Figures}



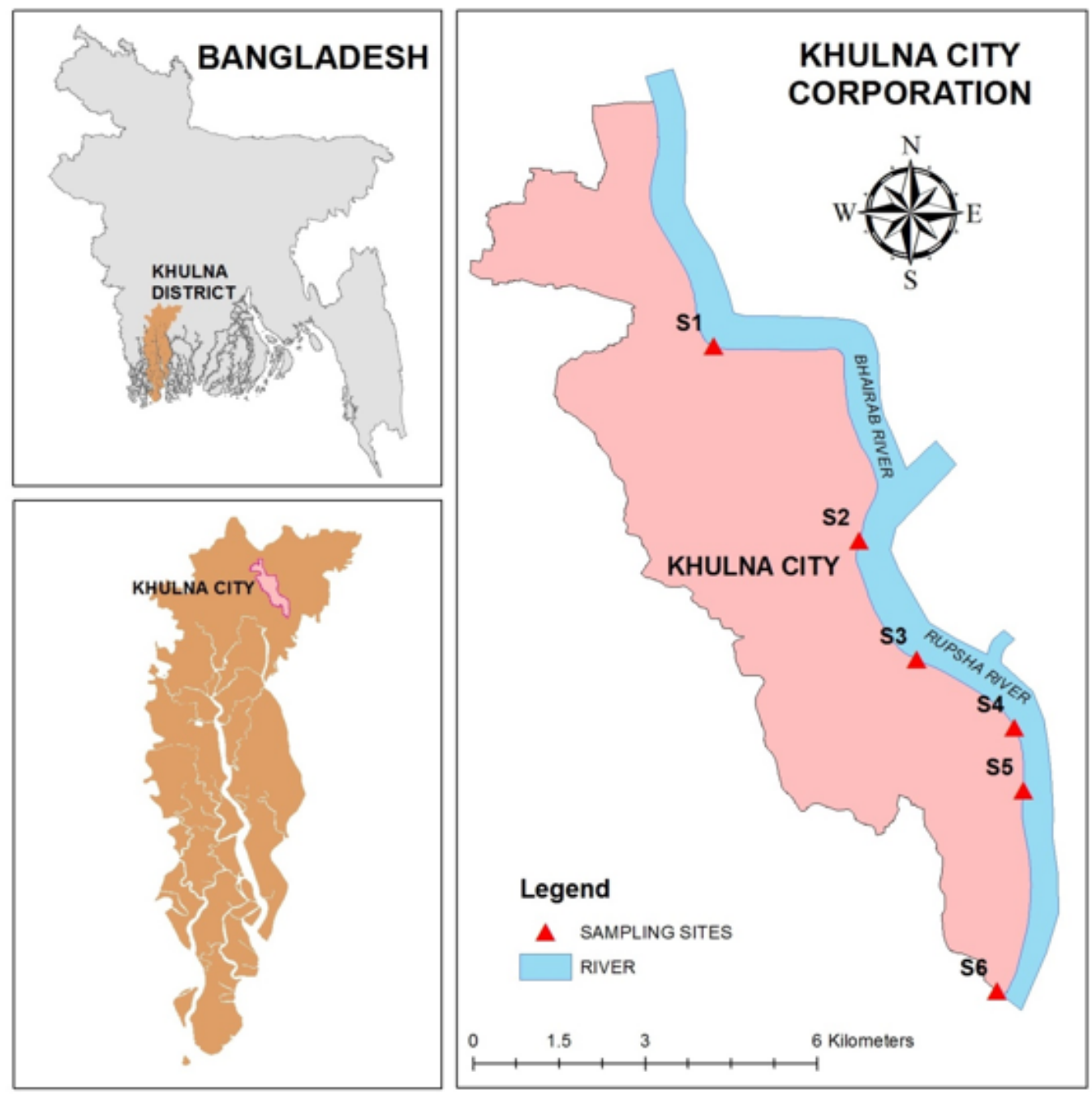

Figure 1

Sampling sites in the Rupsha and Bhairab rivers around Khulna city 


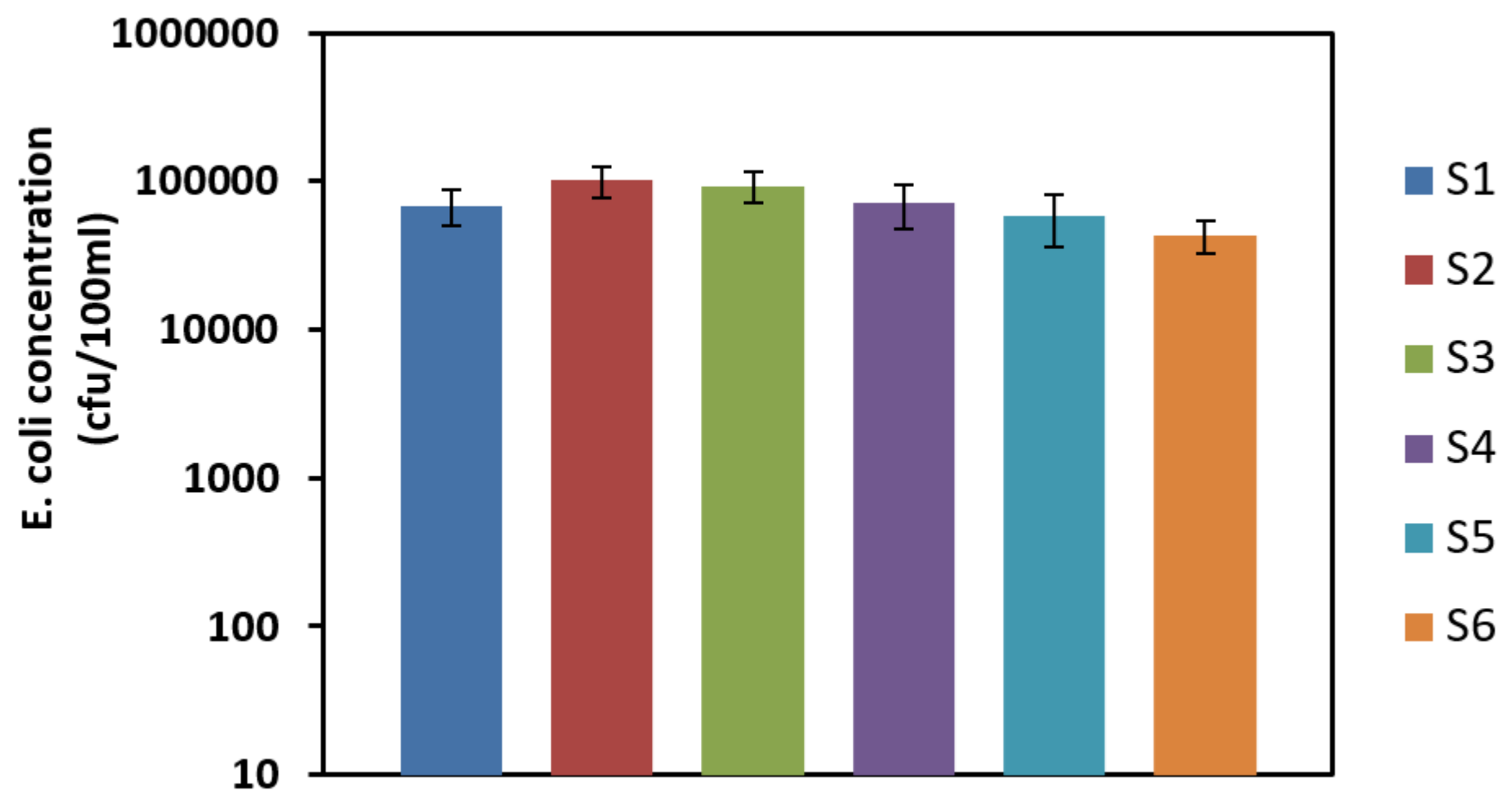

Figure 2

Average E. coli concentrations over the six river sites with standard errors

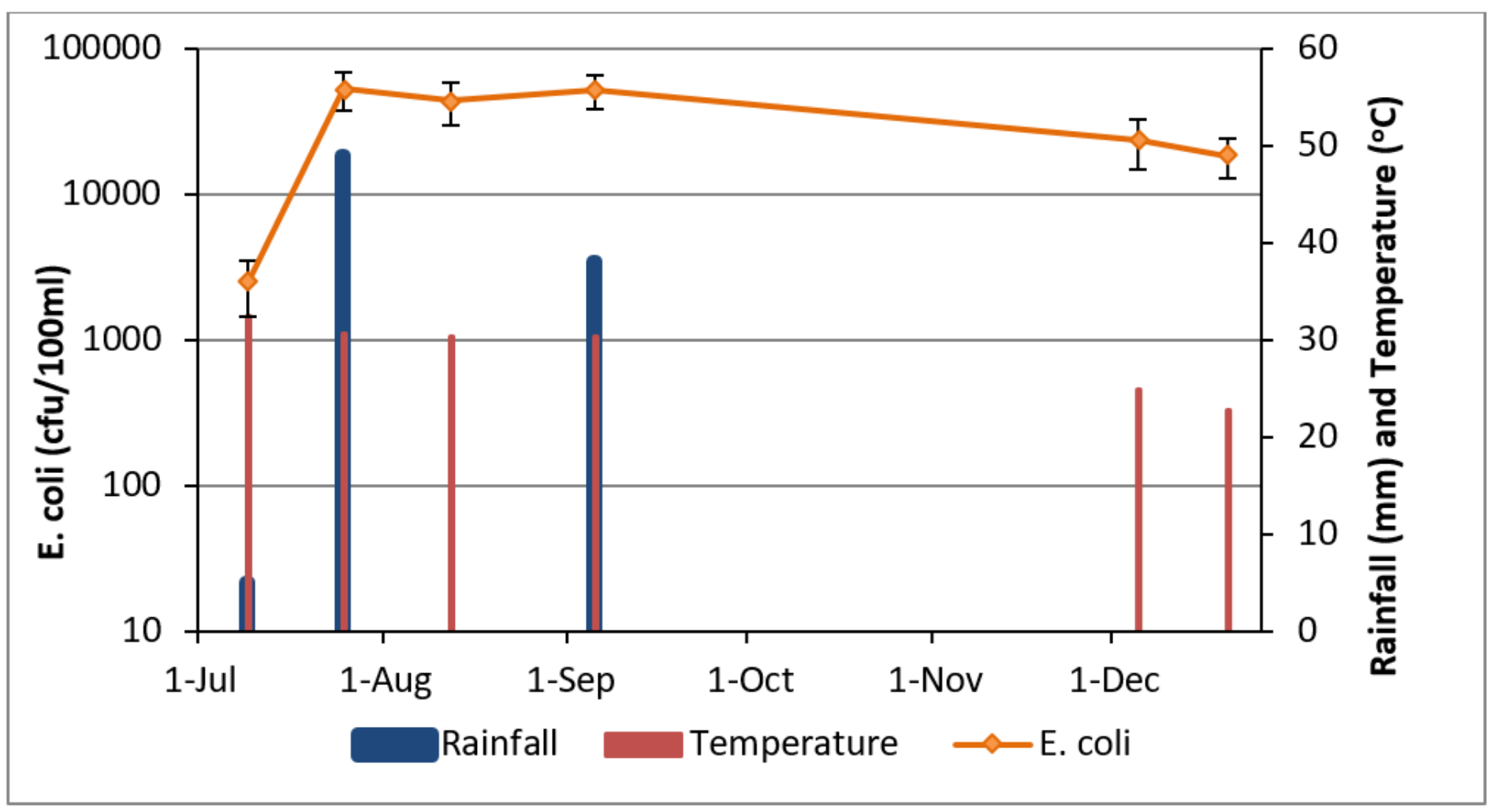

Figure 3 
Average E. coli concentrations (cfu/100 mL) with standard errors, water temperature (oC) and total recorded rainfall (mm, summed over 3 days preceding the sampling day) over the six river sites.
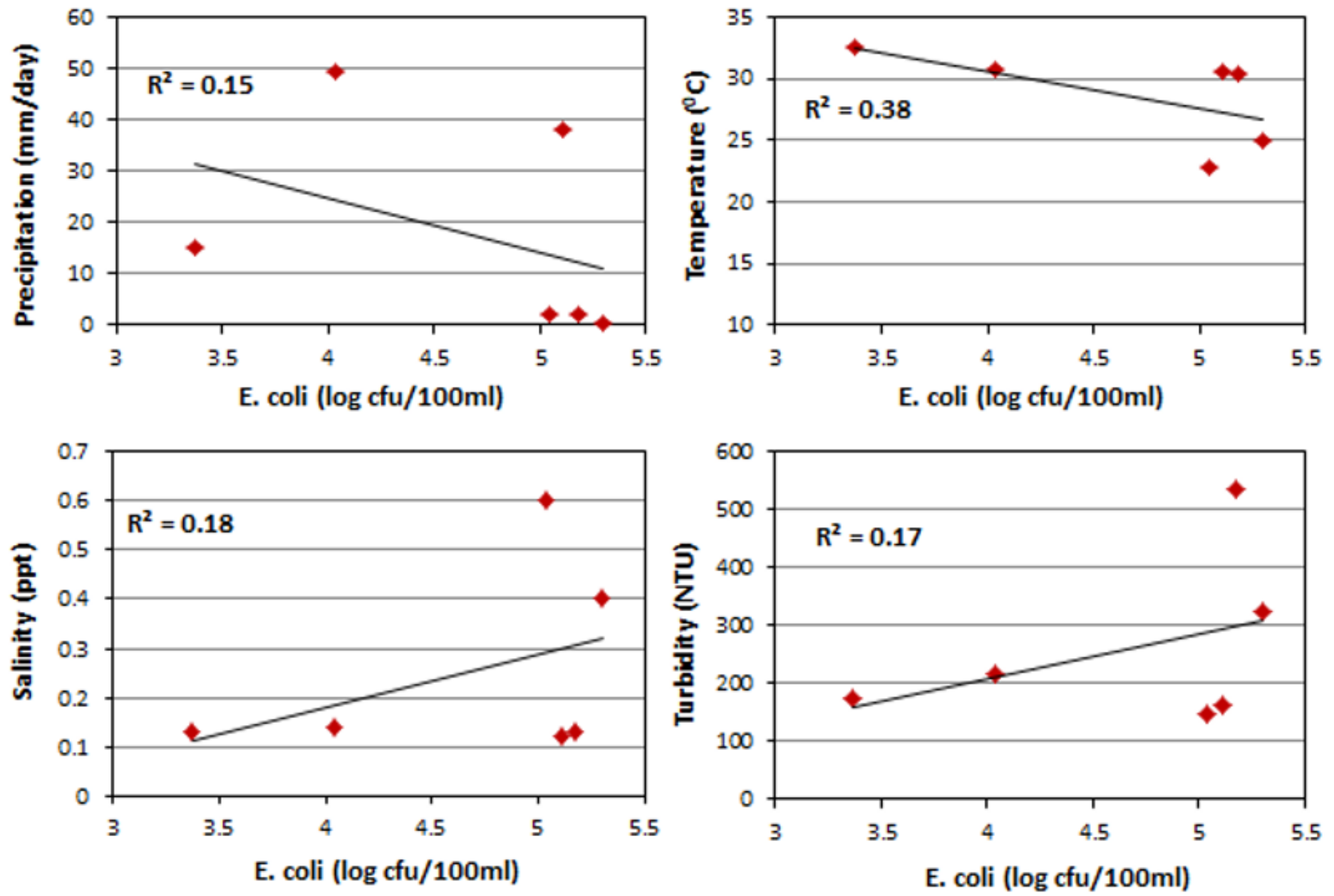

Figure 4

Correlations of $\log 10 \mathrm{E}$. coli (average over the river sites) with precipitation, water temperature, salinity and turbidity. 


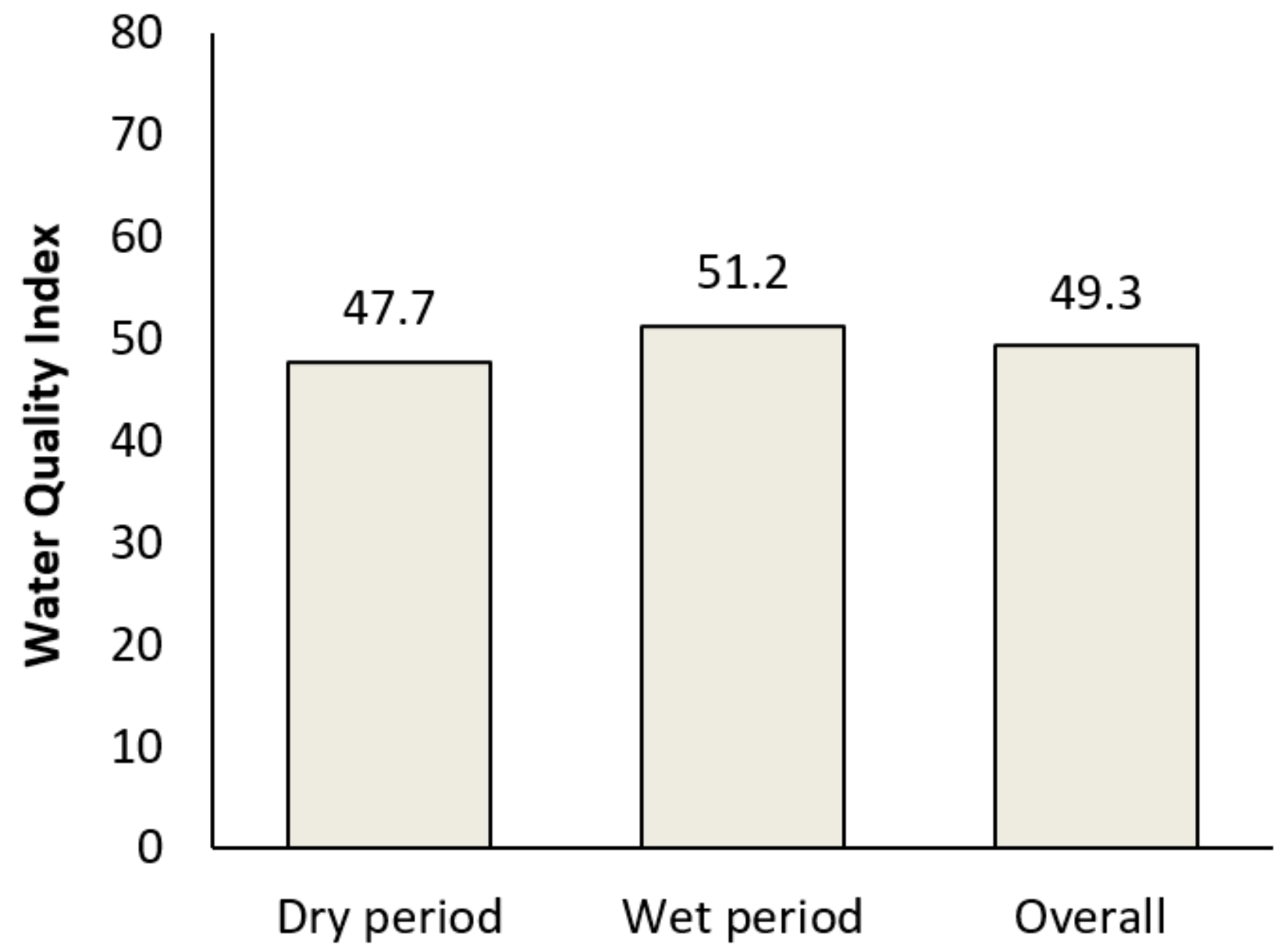

Figure 5

Water quality index of Rupsha and Bhairab rivers, average over the sampling sites. 